\section{COMMITTEE ON NON-WESTERN RESOURCES}

\section{Activities and Plans}

In the early months of 1964 Ward Morehouse (director of the Foreign Area Materials Center, State Education Department of New York) and Jackson Bailey (professor of history, Earlham College) as members of the Committee on Undergraduate Education of the Association for Asian Studies, wrote to the officers of ACRL, expressing the concern of the Association for Asian Studies in developing programs of Asian studies at the undergraduate level. In promoting these programs the Association realized the inadequacy of library collections and that many librarians had neither the experience nor the knowledge to develop such collections. The Association hoped that librarians might become concerned about this matter as well.

This appeal to ACRL resulted in the establishment of the Committee on Non-Western Resources under the College Libraries Section. The first meetings, spaced and paced by the ALA sessions of Midwinter and annual conferences, were exploratory. Representatives from groups interested in these developments were invited to meet with the committee: the Asia Society, the Association of American Colleges, the Library of Congress, the United States Office of Education. One element recurred throughout all the discussions: the work of the committee should be directed towards librarians of those undergraduate colleges with small library collections. Their problems were completely different from the large universities which were developing extensive and specialized collections. In these institutions there were usually both librarians and faculty with knowledge and experience of materials in non-Western areas. It was the librarians of the smaller colleges who needed to be informed and assisted in the scope of materials in the subject field as well as in their acquisition and processing.

The activities of the committee have taken two directions. One has been in the form of instructional meetings: a pre-conference at Douglass College in 1966 prior to the ALA meetings in New York, the program meeting of the College Libraries Section in 1967 at the time of the ALA meetings in San Francisco, and for this year, another preconference before the ALA meetings in Kansas City. The format of these sessions were influenced by a week-long institute held at Earlham College by the Great Lakes Colleges Association in 1965. Teaching faculty were asked to participate and the essence of these programs has been the exchange between faculty and li- brarian-between those who were teaching courses on non-Western areas and those whose responsibility it was to develop the library collection which is needed to support the teaching program. Representatives from professional associations and related organizations were also involved: the Middle East Institute, the American Universities Field Staff, Education and World Affairs, and others.

The committee's other role has been as advisor and consultant to the Foreign Area Materials Center in a contract it has with the United States Office of Education. The project involves the preparation of a series of bibliographies on East Asia, South Asia, and Africa south of the Sahara which are specifically directed towards undergraduate libraries. These bibliographies, in their preliminary form, will be ready for discussion by the committee at the time of the preconference at Kansas City in June.

With the Kansas City preconference the committee will have carried its message from the East Coast to the West Coast and South. The planning of its future activities will be reviewed at that time, but they will be in line with the Statement of Purpose of the committee:

The role of the Committee on Non-Western Resources of the College Libraries Section of the Association of College and Research Libraries is to identify the bibliographic, staff and acquisitions problems with which college libraries are faced in supporting and implementing programs for the study of non-Western areas at the undergraduate level; to identify professional associations and information sources concerned with such programs; to maintain liaison with these associations as well as with other American Library Association committees also concerned with non-Western programs; and to disseminate information thus acquired to college librarians through whatever means seem appropriate.

The first chairman of the committee was Charles M. Adams (University of North Carolina at Greensboro); the second, Anne C. Edmonds (Mount Holyoke College); and the present one, André Nitecki (School of Library Science, Syracuse University). Past and present members of the committee are: Paul H. Bixler (Antioch College), Bruce M. Brown (Colgate University), Jean Black (Portland State College), Dorothy Drake (Scripps College), Evan I. Farber (Earlham College), Mother E. O'Connor (Manhattanville College), James H. Richards, Jr. (Carleton College), J. Michael Rothacker (Wabash College), and David Wilder (University of Manitoba)-Anne C. Elmonds. 


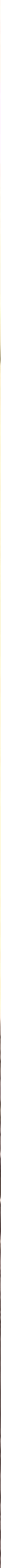




\section{look for things when we've already found them.}

\section{Out-of-Print Bools}

If we don't have the book you're looking for, we'll find it, film it, clear copyright, pay royalties and send it to you.

Whether we find the book in Timbuktu or in our collec tion of 50,000 old and new titles; whether the original is worth $\$ 10$ or $\$ 10,000$, the cost is the same. A penny-anda-third a page for $35 \mathrm{~mm}$ positive microfilm. Four cents a page for a paperbound xerographic copy. Six cents a page for a copy in a foreign language.

\section{American Prose Fiction}

This microfilm series includes almost all of the 5,600 titles in Lyle Wright's definitive bibliography covering the period from 1774 to 1873 .

\section{Early English Books}

Two collections: The first is based on Pollard and Redgrave's short-title catalog, 26,500 titles from 1473-1640. The second includes the Wing bibliography, 90,000 titles published from 1640-1700.

\section{Facsimile Reprints Vanity Fair}

This magazine is an exciting social, political and cultural history of 1913-1936, told in words and pictures by the most talented people of the day. In 33 volumes, plus index, it is an encyclopedia of an era.

\section{The March of America Collection}

One hundred hardbound titles covering 400 years of American history, written by the men who made it. From The "Columbus Letter of 1493" through the closing of the frontier in 1893.

\section{The Legacy Library}

A magnificent collection of classics for children. The original versions. Not a word changed. Not an illustration redrawn. Not a teaching book. But a book to enjoy.

Four different sets. Ten books to a set. Now in print.

\section{Novyi Mir}

Novyi Mir from 1925-1944. A complete uncensored reprint, very rare in both the U.S. and the U.S.S.R.

\section{Equipment}

University Microfilms Reader

Many of our periodicals, books and dissertations are on microfilm. So we also offer a quality microfilm reader. It's portable, easy to use, and it's only $\$ 125$ postpaid Enough said?

That's pretty much the story of University Microfilms. So let us know what you need. We can help you help everybody from school children to doctoral candidates.

We keep over 600,000 old and new titles downstairs in our vaults. But, if what you need isn't here, we'll find it for you. Even if we end up in the Zillerthal Alps like we did last year to microfilm $1 \mathrm{I}$ th and 12 th century manuscripts in monastic scriptoria

Where do you think we'd go for you?

Why should you look for things when we've already found them.

\footnotetext{
Send us your name, address and the numbers of the catalogs you want.

1. Complete Periodicals Reference Catalog

2. Basic and Comprehensive Periodical Collections

3. Catalogs of Out-of-Print Books

A) Bibliography, Library Science, General Work

B) Business and Economics C) Education D) Fine

Arts and Architecture E) History, Political

Science F) Language and Literature G) Law and

Public Administration $\mathrm{H}$ ) Philosophy and

Psychology I) Religion J) Sociology and Statistics.

4. Early American Books and Periodicals

5. American Prose Fiction

6. Early English Literary Periodicals

7. Early English Books

8. Facsimile Reprint Catalog (90 Titles)

9. The March of America Facsimile Collection

10. The Legacy Library

11. Russian Language Books

12. Novyi Mir

13. Microfilm Reader

14. Source Material in the Field of Theatre

15. National Cyclopedia of American Biography
}

University Microfilms, A Xerox Company

304 North Zeeb Road, Ann Arbor, Michigan 48103

\section{XEROX}

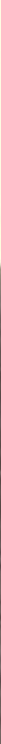

